\title{
Friheden og ligheden
}

\author{
Af Jes Fabricius Møller
}

K. E. Bugge, Grundtvig og slavesagen, Århus, 2003, 226 sider.

Man troede jo efterhånden, at det nye, der kunne fortælles om N. F. S. Grundtvig, var et spørgsmål om fortolkningsnuancer. Og så lærer vi pludselig, at Grundtvig i perioden 1839-1848 var medlem af en komité, hvis formål det var at arbejde for negerslavernes frigivelse i dansk Vestindien.

Det føjer et helt nyt aspekt til synet på Grundtvig, som kun har været berørt ganske lidt i forskningen. Stikordet "slave" eller "slaveri" findes for eksempel slet ikke i J. Borup og Fr. Schrøders Haandbog $i$ N. F. S. Grundtvigs Skrifter, København 1929-31. Nu foreligger der altså en hel bog om emnet. Den er præget af sin forfatters overblik over Grundtvigs forfatterskab og et indgående kendskab til perioden. Bugge bygger udover et omfattende trykt kildemateriale på manuskripter og breve fra Grundtvigs arkiv på det Kongelige Bibliotek, J. F. Schouws arkiv på Rigsarkivet og British and Foreign Anti-Slavery Society's arkiv i Oxford. Bogen giver et klart indtryk af at være nået til bunds i sit emne uden at virke for lang eller kedende.

Negerslaver kaldtes de for at skelne dem fra de straffearbejdere på blandt andet Bremerholm, der også kaldtes 'slaver'. Faktisk blev nogle af disse slaver også sendt til de vestindiske øer, hvor man altså har kendt til hvide slaver. Den begrebslige adskillelse - og hyppige sammenblanding - af hvide og sorte, slaver og frie er behandlet af Louise Sebro i artiklen "Kreoliseringen af eurocaribierne i Dansk Vestindien - sociale relationer og selvopfattelse", Fortid og Nutid, 2005/2, 83-102. Til belysning af dette spørgsmål set fra samtidens synsvinkel bør også fremhæves det Danske Vestindiske Selskabs prisværdige genudgivelse fra 1998 af Henrik Hertz' De 'frifarvede, en roman fra 1836, der sætter racespørgsmålet ind i en romantisk handling.

Grundtvigs omvendelse til slavesagen og oprettelsen af den danske komité fulgte et besøg i København i 1839 af en repræsentant for British and Foreign Anti-Slavery Society, A. W. Alexander, som åbenbart har besiddet en vis overbevisningskraft. Det må betegnes som endnu et eksempel på Grundtvigs bemærkelsesværdige evne til selvrevision, selv i en relativt sen alder. Endnu i 1838 repræsenterede han den opfattelse, at "charity begins at home", det vil sige at problemer prioriteres afhængigt af deres nærhed. I 1841 fik Grundtvig yderligere 
et anstød i mødet med den karismatiske engelske kvækerinde, Elizabeth Fry, der var på besøg i Danmark som fortaler for fængselsreformer. Om dette besøg kan man også læse i Peter Scharff Smiths ph.d.-afhandling, Moralske Hospitaler: det moderne fangselsveesens gennembrud 1770-1870, København 2003, om det danske fængselsvæsens historie. Fry ønskede en mere humanitær behandling af fangerne, herunder ikke mindst ophævelse af den udbredte anvendelse af isolation, men havde i Danmark ringere held med sit forehavende end andre steder.

Bugge gennemgår forudsætningerne for abolitionismen, som bevægelsen for negerslavernes befrielse hed, både hos danske og engelske digtere, politikere og forfattere. Grundtvig var som bekendt meget påvirket af strømningerne i England, hvor friheden var indkapslet i rule of law, sædvaneretten, forstået som modsætning til den franske, revolutionære frihed, der bestod i en kassation af sædvanen.

Komitéen havde til sin opløsning i 1848 en skiftende sammensætning. Den stod i stadig korrespondance med sit britiske modstykke og opnåede takket være prominente medlemmer som D. G. Monrad og J. F. Schouw blandt andet vedtagelsen af en petition til kongen om spørgsmålet på Østifternes stænderforsamling. Mangt og meget blev overhalet af begivenhederne i 1848, og det gælder også slavekomitéens arbejde. Peter v. Scholtens proklamation den 3. juli 1848 til folkemængden om slavernes frigivelse i Frederiksstad på St. Croix blev fulgt op af en regeringserklæring senere på året, der bekræftede befrielsen.

Bugge ser Grundtvigs arbejde i komitéen som en forløber for hans virke som rigsdagsmand. Der er udmærket fornuft i dette ræsonnement, fordi folkestyrets forudsætning var skabelsen af en borgerlig offentlighed, ja, overhovedet en omdannelse af begrebet borger. En borger var i 1840 'erne ikke længere blot en byboer, men en myndig undersåt med et stadig mere højlydt ønske om adkomst til magten. Den ny tids borger blev ikke defineret ved sin plads i hierarkiet, men fandt sin identitet først og fremmest i kraft af ligheden med sine medborgere. Ironisk nok bidrog den enevældige konges principielle men langtfra realistiske - krav på al magt i landet til hans undersåtters følelse af lighed med hinanden. I praksis skabte Frederik VI med de rådgivende stænderforsamlinger en forsøgsopstilling af det demokrati, der blev indført få år senere.

Det er interessant at bemærke som en parallel til slavesagen, at Grundtvig gik varmt ind for jødernes ligestilling med deres kristne medborgere. Det forholdt sig nemlig således, at jøderne trods det så- 
kaldte frihedsbrev af 1814 ikke var valgbare til stænderforsamlingerne. Grundtvig talte for jødernes lige ret til at nyde repræsentation i de valgte forsamlinger med det argument, at de havde vist sig at være gode og nyttige borgere. Det er behandlet af Martin Schwarz Lausten i Frie jøder? - Forholdet mellem kristne og jøder $i$ Danmark fra Frihedsbrevet 1814 til Grundloven 1849, København 2005, som giver en passende modvægt til Grundtvigs ofte fremhævede bemærkninger om jøderne $\mathrm{i}$ hans diskussion med Goldschmidt.

Sammenlagt må Bugges bog hilses velkommen som et korrektiv til det ikke så flatterende billede, der i disse år gives af Grundtvig. Vores tid har udviklet en forståelig og berettiget afsmag for den nationalisme, som Grundtvig også repræsenterede. Men vi har beholdt forkærligheden for den borgerlige frihed og lighed, hvis rødder bør være lige så kendte. Tak for oplysningen, Bugge. 